\title{
Effects of Central Injection of Anti-LPS Antibody and Blockade of TLR4 on GnRH/LH Secretion during Immunological Stress in Anestrous Ewes
}

\author{
Karolina Haziak, Andrzej Przemysław Herman, and Dorota Tomaszewska-Zaremba
}

The Kielanowski Institute of Animal Physiology and Nutrition, Polish Academy of Sciences, 05-110 Jabłonna, Poland

Correspondence should be addressed to Karolina Haziak; karolina.haziak@gmail.com

Received 7 November 2013; Revised 19 December 2013; Accepted 27 December 2013; Published 11 February 2014

Academic Editor: Dariusz J. Skarzyński

Copyright (C) 2014 Karolina Haziak et al. This is an open access article distributed under the Creative Commons Attribution License, which permits unrestricted use, distribution, and reproduction in any medium, provided the original work is properly cited.

\begin{abstract}
The present study was designed to examine the effect of intracerebroventricular (icv) administration of antilipopolysaccharide (LPS) antibody and blockade of Toll-like receptor 4 (TLR4) during immune stress induced by intravenous (iv) LPS injection on the gonadotropin-releasing hormone/luteinizing hormone $(\mathrm{GnRH} / \mathrm{LH})$ secretion in anestrous ewes. Injection of anti-LPS antibody and TLR4 blockade significantly $(P<0.01)$ reduced the LPS dependent lowering amount of $G n R H$ mRNA in the median eminence (ME). Moreover, blockade of TLR4 caused restoration of $L H-\beta$ transcription in the anterior pituitary decreased by the immune stress. However, there was no effect of this treatment on reduced LH release. The results of our study showed that the blockade of TLR4 receptor in the hypothalamus is not sufficient to unblock the release of LH suppressed by the immune/inflammatory challenges. This suggests that during inflammation the LH secretion could be inhibited directly at the pituitary level by peripheral factors such as proinflammatory cytokines and circulating endotoxin as well.
\end{abstract}

\section{Introduction}

An immune stress inhibits reproductive functions in many animal species and humans [1-4]. Most studies examined the impact of immune stress on reproductive system activity that used bacterial endotoxin lipopolysaccharide (LPS) as a model of infection induced changes. Lipopolysaccharide is a pathogenic membrane component of virtually all Gramnegative bacteria and it is released from the surface of replicating and dying Gram-negative bacteria into the circulation [5]. Bacterial endotoxin is thought to play a major role in the pathophysiology of septic shock [2]. Endotoxin stimulation of animal cells occurs through a signalling cascades with several proteins including CD14 protein, MD-2 protein, and LPS-binding protein (LBP), a necessary component of corresponding LPS receptor called Toll-like receptor 4 (TLR4) $[6,7]$. LPS enters the bloodstream associated with LBP. Then, LPS-LBP complex binds to the CD14 protein, which is necessary for the activation of TLR4. CD14, MD-2, and TLR4 as a whole make up the cellular LPS specific receptor $[8,9]$. After activation by endotoxin, TLR4 transduces its inflammatory signal through complex intracellular pathways, leading to activation of transcription factors such as nuclear factor kappa-light-chain-enhancer of activated B cells (NF$\kappa \mathrm{B}$ ), c-Jun N-terminal kinase (JNK), and protein kinases $\mathrm{p} 38$ or inducing cell apoptosis $[10,11]$.

Administration of LPS inhibits tonic luteinizing hormone (LH) secretion in many species including rats [12], sheep [13], cattle [1], and nonhuman primates [4] as well as delays or completely blocks the preovulatory LH surge [14]. In our earlier studies carried out on anestrous ewes, we showed that suppressive effect of LPS on GnRH/LH secretion occurs primarily at the level of hypothalamus, changing the gonadotropin-releasing hormone $(\mathrm{GnRH})$ synthesis and release as well at the pituitary level by inhibiting release of $\mathrm{LH}$ from gonadotropic cells $[15,16]$.

Data from literature indicate the existence of many possible mechanisms mediating antireproductive action of immune stress. It was shown that the crucial role in the mediation of the inhibitory influence of inflammation on $\mathrm{GnRH} / \mathrm{LH}$ secretion play the role of proinflammatory cytokines such as IL-1, IL-6, TNF- $\alpha[17,18]$. The results of 
our studies showed that IL- $1 \beta$ is one of the most important factors in modulating the function of $\mathrm{GnRH}$ neurons in anestrous ewes during immune stress [19]. However, cytokine dependent pathway is not only mechanism via an immune challenge that affects the reproduction processes in animals. The studies on ewes in anestrous period indicated the presence of TLR $4 \mathrm{mRNA}$ in the hypothalamic structures such as the preoptic area (POA), the anterior hypothalamic area (AHA), the medial basal hypothalamus $(\mathrm{MBH})$, the median eminence (ME), and in the anterior pituitary gland (AP) in control animals as well as after LPS treatment. The expression of the gene encoding this receptor in ewes treated with LPS was significantly higher than that determined in control animals [20]. It is worth to note that TLR4 expression was found in the central nervous system (CNS) not only in microglia cells, but even in neurons [21]. This suggests that TLR4 and its ligand LPS could be involved in inhibition of the reproductive function at the CNS and directly influence $\mathrm{GnRH} / \mathrm{LH}$ secretion at the hypothalamic or pituitary level. The question of the possible penetration of endotoxin from blood to the cerebrospinal fluid (CSF) during immune stress and thus direct LPS action at the brain level is still open because the results of in vivo studies are not equivocal. The study performed on rats showed that peripherally injected LPS labelled with iodine 125 crossed the blood-brain barrier (BBB). Although the brain uptake of circulating LPS was found to be low, it was measurable [22]. On the other hand, Singh and Jiang [23] suggested that LPS modulates the functioning and permeability of the BBB but does not cross it.

The research hypothesis assumes that LPS given peripherally (intravenously-iv) can directly affect the hypothalamicpituitary-gonadal axis (HPG) at the CNS level that was verified.

The aim of our experiments was to study the influence of the intracerebroventricular (icv) injection of anti-LPS antibody or blockade of TLR4 receptor during immune stress induced by iv LPS administration on the GnRH/LH secretion and TLR4 gene expression in hypothalamus and pituitary of anestrous ewes.

\section{Materials and Methods}

2.1. Animals. The studies were conducted on adult, 3-year-old Polish Longwool ewes in the anestrous season (April-May). All animals were in good condition, and their body condition score was estimated at 3 points (on a five-point scale). The animals were maintained indoors in individual pens and exposed to natural daylight. The ewes were well adapted to the experimental conditions; they always had visual contact with their neighbours, even during the experimental period, to prevent the stress of social isolation. The animals were fed a constant diet of commercial concentrates with hay and water available ad libitum. One month before starting of the experiment all groups of ewes were cannulated with stainless steel guide cannulas $(1.2 \mathrm{~mm}$ o.d.) into the third ventricle under stereotaxic control [24]. The guide cannula was fixed to the skull with stainless steel screws and dental cement. The correct placement of the guide cannula into the third ventricle was established by the efflux of the cerebrospinal fluid from cannula during the surgery. Additionally, the placement of the cannula was checked by inspection of the brain after decapitation. All animals had a venous catheters implanted into jugular vein the day before the experiment.

All experimental procedures were performed in accordance with the Polish Guide for the Care and Use of Animals (1997) and were approved by the Local Ethics Committee of the Warsaw University of Life Sciences.

\subsection{Experimental Procedures}

2.2.1. Inducing Immune Stress in the Experimental Animals. Immune stress was induced in treated animals by intravenous (iv) bolus injection of an appropriate volume of LPS ( $400 \mathrm{ng} / \mathrm{kg}$ body weight) from $E$. coli 055:B5 (Sigma-Aldrich, St. Louis, MO, USA) dissolved in saline $(0.9 \% \mathrm{w} / \mathrm{v} \mathrm{NaCl})$ (Baxter, Deerfield, IL, USA) at a concentration of $10 \mathrm{mg} / \mathrm{L}$ into the jugular vein. The maximum volume of LPS solution $(10 \mathrm{mg} / \mathrm{L})$ administered to any animal was $2.5 \mathrm{~mL}$. The control group received an equivalent volume of saline.

2.2.2. Experimental Schedule. The animals $(n=20)$ were randomly assigned to four experimental groups: (1) "NaCl control group" ( $n=5)$, received intracerebroventricular (icv) injection of Ringer-Locke's solution (RLs) into the third ventricle of the brain and 15 min later iv injection of $\mathrm{NaCl}$; (2) "LPS control group" ( $n=5)$, received RLs (icv) and $15 \mathrm{~min}$ later LPS (iv); (3) “anti-LPS group" ( $n=5)$, received monoclonal anti-LPS antibody (Abcam, Cambridge, UK) (icv) in dose of $10 \mu \mathrm{g} /$ animal and $15 \mathrm{~min}$ later LPS (iv); (4) "antiTLR4 group", received (icv) antibodies binding TLR4 receptor complex components, anti-LBP (Abcam, Cambridge, UK) in dose of $20 \mu \mathrm{g} / \mathrm{animal}$, and anti-MD2 (Abcam, Cambridge, UK) in dose of $10 \mu \mathrm{g} /$ animal and 15 min later LPS (iv). All antibodies were dissolved in sterile RLs.

Jugular blood samples from each ewe were taken for $\mathrm{LH}$ and cortisol measurement at $15 \mathrm{~min}$ intervals, beginning $2 \mathrm{~h}$ before endotoxin or saline injection (iv) preceded by the injection of appropriate substances (icv), and continuing $4 \mathrm{~h}$ after LPS or saline treatment.

Effect of Immune Stress on the Gene Expression in Hypothalamic Structures and in the AP. After 2 weeks of convalescence, the same animals $(n=20)$ were used. Hypothalamic structures (the preoptic area-POA, the anterior hypothalamic area-AHA, the medial basal hypothalamus- $\mathrm{MBH}$, and the median eminence-ME) and the anterior pituitary glands (AP) were collected $2 \mathrm{~h}$ after iv injection of LPS or saline preceded by the icv injection of corresponding substances as described above. The animals were slaughtered by decapitation, the brains were rapidly removed from the skulls, and then chosen hypothalamic structures and APs were dissected. All tissues were frozen immediately after collection in liquid nitrogen and were stored in $-80^{\circ} \mathrm{C}$ until assay. 


\subsection{Assays}

2.3.1. Radioimmunoassay for $L H$. The concentration of LH in plasma was assayed by the radioimmunoassay (RIA) doubleantibody method using anti-ovine-LH and anti-rabbit- $\gamma$ globulin antisera and ovine standard (NIH-LH-SO18) as described by Stupnicki and Madej [25]. The sensitivity was $0.3 \mathrm{ng} / \mathrm{mL}$; intra-assay and interassay coefficients of variation were $8.3 \%$ and $12.5 \%$, respectively.

2.3.2. Radioimmunoassay for Cortisol. The cortisol concentrations were determined by the RIA method according to Kokot and Stupnicki [26], using rabbit anticortisol antisera (R/75) and HPLC grade cortisol standard (Sigma). The assay sensitivity was $0.95 \mathrm{ng} / \mathrm{mL}$ and the intra-assay and interassay coefficients of variation were $10 \%$ and $12 \%$, respectively.

2.3.3. Relative Gene Expression Assays. Total RNA from hypothalamic and pituitary tissues was isolated using NucleoSpin RNA II Kit (MACHEREY-NAGEL Gmbh \& Co, Düren, Germany) according to manufacturer's protocol. The purity and concentration of isolated RNA were quantified spectrophotometrically by measuring the optical density at 260 and $280 \mathrm{~nm}$ in a NanoDrop 1000 instrument (Thermo Fisher Scientific Inc., Waltham, USA). The RNA integrity was verified by electrophoresis using $1 \%$ agarose gel stained with ethidium bromide. DyNAmo SYBR Green 2-Step qRT-PCR Kit (Finnzymes, Espoo, Finland) was used to prepare cDNA synthesis. As a starting material for this PCR synthesis $800 \mathrm{ng}$ of total RNA was used.

Real-time RT-PCR was carried out using SYBR Green 2Step qRT-PCR Kit (Finnzymes, Espoo, Finland) components and HPLC-grade oligonucleotide primers synthesized by Genomed (Poland). Specific primers for determining the expression of housekeeping genes and the genes of interest (Table 1) were designed using Primer 3 software. One tube contained $10 \mu \mathrm{L}$ PCR Master Mix (2x), $7 \mu \mathrm{L}$ RNase-free water, $2 \mu \mathrm{L}$ primers $(1 \mu \mathrm{L}$ each, working concentration was $0.5 \mu \mathrm{M})$, and $1 \mu \mathrm{L} \mathrm{cDNA}$ template. The tubes were run on the Rotor-Gene 6000 (Qiagen, Duesseldorf, Germany). The following protocol was used: $95^{\circ} \mathrm{C}$ in $15 \mathrm{~min}$ for activating Hot Start DNA polymerase and finally the PCR including 30 cycles at $94^{\circ} \mathrm{C}$ in $5 \mathrm{sec}$ for denaturation, $56^{\circ} \mathrm{C}$ in $20 \mathrm{sec}$ for annealing, and $72^{\circ} \mathrm{C}$ in $15 \mathrm{sec}$ for extension. After the cycles, a final melting curve analysis under continuous fluorescence measurements was performed to confirm the specificity of the amplification.

\subsection{Data Analysis}

2.4.1. Plasma Hormones Concentration Data Analysis. All data are presented as hormone concentration expressed as mean \pm SEM. The results of LPS treatments on the concentrations of plasma LH and cortisol were examined by two-way analysis of variance-ANOVA (STATISTICA; StatSoft, Inc., Tulsa, OK, USA) to identify treatment effects and significant interactions between the control and experimental groups. All experiments consisted of a baseline period when no treatment was given ( -2 to $0 \mathrm{~h}$ before) and period when treatments were applied $(+1$ to $+4 \mathrm{~h}$ after LPS or saline injection). Data was integrated over time. ANOVA for hormone parameters excluded data during the first hour after LPS or saline treatment to allow time for treatments to take effect. When a significant treatment by time interaction was observed, post hoc analysis was conducted to identify treatment effects. The Mann-Whitney $U$ test was used to compare pre- versus posttreatment values.

2.4.2. PCR Data Analysis. Relative gene expression was calculated using the comparative quantification option of Rotor Gene 6000 software 1.7 (Qiagen, Duesseldorf, Germany). The second differential maximum method [27] was used in this analysis to calculate reaction efficiencies and a set percentage of the maximum fluorescence value to calculate the beginning of the exponential phase. To compensate a variation in CDNA concentrations and the PCR efficiency between tubes, an endogenous control gene was assayed in each sample and used for normalization. Initially, three housekeeping genes glyceraldehyde-3-phosphate dehydrogenase (GAPDH), $\beta$-actin (ACTB), and cyclophilin C (PPIC) were tested. The BestKeeper was used to determine the most stable housekeeping gene, for normalizing genes of interest expression. The BestKeeper was based on the pair-wise correlation analysis of all pairs of candidate genes [28] and calculates variations of all reference genes $(\mathrm{SD}( \pm \mathrm{Ct})$ ). PPIC was chosen as the best endogenous control gene. It had the lowest $\mathrm{SD}( \pm \mathrm{Ct})$ value and a good correlation coefficient with the remaining analysed housekeeping genes.

The results are presented as relative gene expression of the target gene versus housekeeping gene, relative expression value and mean \pm SEM. The average relative quantity of gene expression in control groups was set to 1.0. The significance of differences between the experimental groups was assessed by the Mann-Whitney $U$ test.

\section{Results}

3.1. Effect of Central Injection of Anti-LPS Antibody and Blockade of TLR4 on Cortisol Release during LPS-Induced Inflammation. LPS administration significantly $(P<0.01)$ increased plasma cortisol level in all LPS-treated groups (LPS control, anti-LPS, anti-TLR4) compared with $\mathrm{NaCl}$ control group (Figure 1).

\subsection{Effect of Central Injection of Anti-LPS Antibody and} Blockade of TLR4 on LH Secretion during LPS-Induced Inflammation. Intravenous injection of LPS significantly reduced plasma LH release in all LPS-treated groups (LPS control: $P<$ 0.01; anti-LPS: $P<0.05$; anti-TLR4: $P<0.05)$ compared with the saline control. The central administration of anti-LPS as well as icv injection of anti-LBP and anti-MD2 did not influence on lowered LH secretion (Figure 2).

Peripheral administration of endotoxin significantly $(P<$ $0.05)$ decreased the gene expression of $L H-\beta$ in the AP in LPS control and anti-LPS groups compared with $\mathrm{NaCl}$ control group. On the other hand, injection of antibodies binding 
TABLE 1: Specific primers used in real-time PCR for determining the expression of housekeeping genes and genes of interests.

\begin{tabular}{|c|c|c|c|c|}
\hline Gene bank acc. number & Gene & Amplicon size [bp] & Forward/reverse & Sequence $5^{\prime} \rightarrow 3^{\prime}$ \\
\hline \multirow{2}{*}{ NM_001034034 } & \multirow{2}{*}{$\begin{array}{l}\text { GAPDH } \\
\text { glyceraldehyde-3-phosphate } \\
\text { dehydrogenase }\end{array}$} & \multirow{2}{*}{134} & Forward & AGAAGGCTGGGGCTCACT \\
\hline & & & Reverse & GGCATTGCTGACAATCTTGA \\
\hline \multirow{2}{*}{ U39357 } & \multirow{2}{*}{$\begin{array}{l}A C T B \\
\text { beta actin }\end{array}$} & \multirow{2}{*}{168} & Forward & CTTCCTTCCTGGGCATGG \\
\hline & & & Reverse & GGGCAGTGATCTCTTTCTGC \\
\hline \multirow{2}{*}{ NM_001076910 } & \multirow{2}{*}{$\begin{array}{l}\text { PPIC } \\
\text { cyclophilin C }\end{array}$} & \multirow{2}{*}{131} & Forward & ACGGCCAAGGTCTTCTTTG \\
\hline & & & Reverse & TATCCTTTCTCTCCCGTTGC \\
\hline \multirow{2}{*}{ U02517 } & \multirow{2}{*}{$\begin{array}{l}\text { GnRH } \\
\text { gonadotropin-releasing hormone }\end{array}$} & \multirow{2}{*}{123} & Forward & GCCCTGGAGGAAAGAGAAAT \\
\hline & & & Reverse & GAGGAGAATGGGACTGGTGA \\
\hline \multirow{2}{*}{ X52488 } & \multirow{2}{*}{$\begin{array}{l}L H-\beta \\
\text { luteinizing hormone beta-subunit }\end{array}$} & \multirow{2}{*}{184} & Forward & AGATGCTCCAGGGACTGCT \\
\hline & & & Reverse & TGCTTCATGCTGAGGCAGTA \\
\hline \multirow{2}{*}{ NM_001009397 } & \multirow{2}{*}{$\begin{array}{l}\text { GnRH-R } \\
\text { gonadotropin-releasing hormone } \\
\text { receptor }\end{array}$} & \multirow{2}{*}{150} & Forward & TCTTTGCTGGACCACAGTTAT \\
\hline & & & Reverse & GGCAGCTGAAGGTGAAAAAG \\
\hline \multirow{2}{*}{ AY957615 } & \multirow{2}{*}{$\begin{array}{l}\text { TLR4 } \\
\text { Toll-like receptor } 4\end{array}$} & \multirow{2}{*}{117} & Forward & GGTTCCCAGAACTGCAAGTG \\
\hline & & & Reverse & GGATAGGGTTTCCCGTCAGT \\
\hline
\end{tabular}

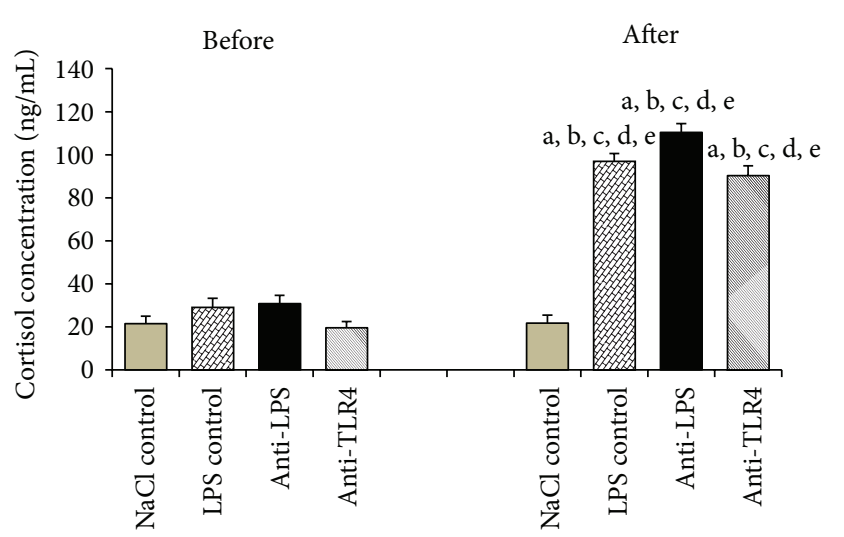

FIGURE 1: The effect of central injection of LPS antibody and blockade of TLR4 on cortisol release before and after LPS or saline treatment. Data are presented as a mean value \pm SEM; letters indicate values that differ significantly according to the Mann-Whitney $U$ test from "NaCl control before" ( ${ }^{\mathrm{a}} \mathrm{P}<0.01$ ); "NaCl control after" ( $\left.{ }^{\mathrm{b}} P<0.01\right)$; "LPS control before" ( $\left.{ }^{\mathrm{c}} P<0.01\right)$; "anti-LPS before" ( ${ }^{\mathrm{d}} P<0.01$ ); "anti-TLR4 before" ( $\left.{ }^{\mathrm{e}} P<0.01\right)$, respectively.

TLR4 receptor complex components anti-LBP and anti-MD2 (anti-TLR4 group) released $L H-\beta$ gene expression from the suppressive effect of LPS administration (Figure 3 ).

3.3. Effect of Central Injection of Anti-LPS Antibody and Blockade of TLR4 on GnRH and GnRH-R Genes Expression during LPS-Induced Inflammation. Injection of LPS significantly $(P<0.01)$ decreased $G n R H$ gene expression in LPS control group from hypothalamic structures such as the POA (by 54\%) and the ME (by 50\%) compared with $\mathrm{NaCl}$ control group. In the $\mathrm{ME}$, the central administration of anti-LPS antibody (anti-LPS group) and antibodies binding TLR4 receptor complex components anti-LBP and anti-MD2 (anti-TLR4 group) significantly $(P<0.01)$ reduced LPS

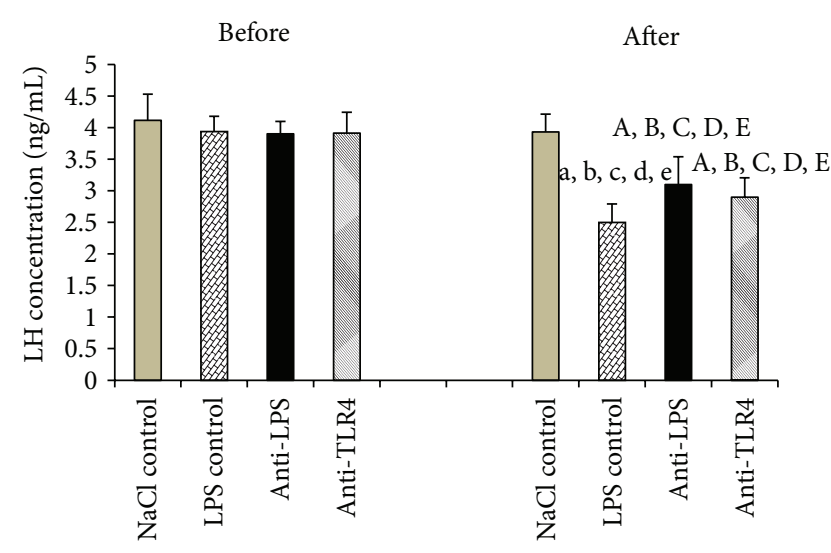

FIGURE 2: The effect of central injection of LPS antibody and blockade of TLR4 on LH release before and after LPS or saline treatment. Data are presented as a mean value \pm SEM. Letters indicate values that differ significantly according to the MannWhitney $U$-test from "NaCl control before" ( ${ }^{\mathrm{a}} P<0.01$; ${ }^{\mathrm{A}} \mathrm{P}<0.05$ ); "NaCl control after" ( ${ }^{\mathrm{b}} P<0.01$; $\left.{ }^{\mathrm{B}} P<0.05\right)$; "LPS control before" ( ${ }^{\mathrm{c}} P<0.01$; $\left.{ }^{\mathrm{C}} P<0.05\right)$; "anti-LPS before" ( $\left.{ }^{\mathrm{d}} P<0.01 ;{ }^{\mathrm{D}} P<0.05\right)$; "anti-TLR4 before" ( ${ }^{\mathrm{e}} P<0.01 ;{ }^{\mathrm{E}} P<0.05$ ), respectively.

dependent suppression of $G n R H$ gene expression compared with LPS control group. No effects of iv and icv treatments on $G n R H$ expression were found in the $\mathrm{MBH}$. The amount of $G n R H$ mRNA determined in the AHA was too low and did not enable the quantitative analysis in this hypothalamic structure (Figure 4).

Gene expression of receptor for $G n R H-R$ significantly $(P<0.01)$ decreased in LPS control groups in the ME and in the AP compared with $\mathrm{NaCl}$ control group. Central administration of anti-LPS or antibodies binding TLR4 receptor complex components anti-LBP and anti-MD2 did not affect 


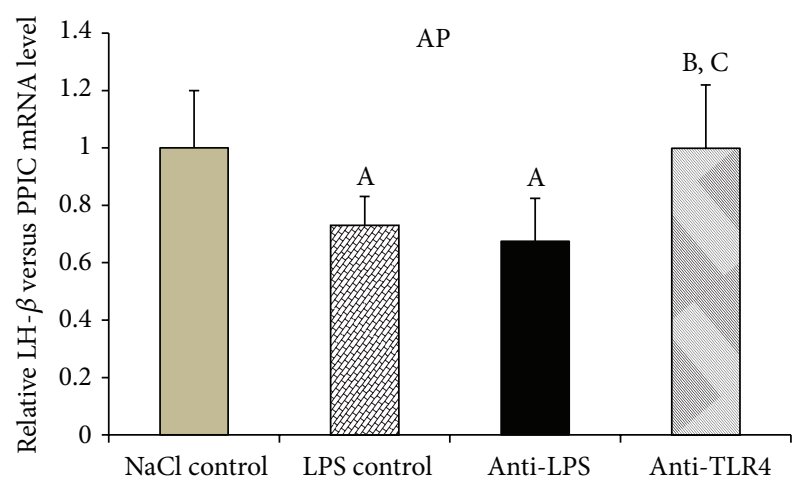

FIGURE 3: The effect of central injection of LPS antibody and blockade of TLR 4 on the relative $L H-\beta$ mRNA level in the anterior pituitary gland during LPS-induced inflammation. Data are presented as a mean value \pm SEM. Letters indicate values that differ significantly according to the Mann-Whitney $U$ test from "NaCl control" ( $\left.{ }^{\mathrm{A}} P<0.05\right)$; "LPS control" ( $\left.{ }^{\mathrm{B}} P<0.05\right)$; "anti-LPS" $\left({ }^{\mathrm{C}} P<\right.$ $0.05)$, respectively.

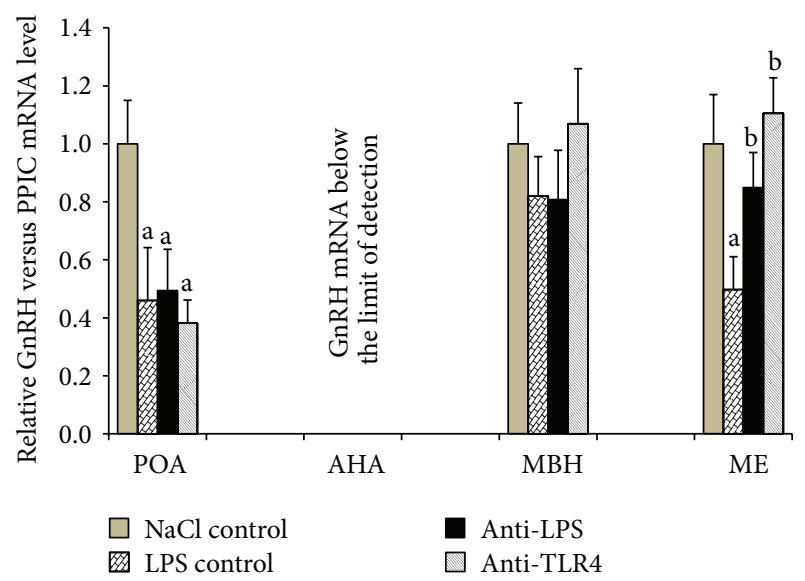

FIGURE 4: The effect of central injection of LPS antibody and blockade of TLR4 on the relative GnRH mRNA level in the hypothalamic structures (POA, AHA, MBH, and ME) during LPSinduced inflammation. Each point represents mean \pm SEM. Letters indicate values that differ significantly according to the MannWhitney $U$ test from "NaCl control" ( ${ }^{\mathrm{a}} P<0.01$ ); "LPS control" $\left({ }^{\mathrm{b}} \mathrm{P}<0.01\right)$, respectively.

$G n R H-R$ gene expression compared to LPS control group (Figure 5).

\subsection{Effect of Central Injection of Anti-LPS Antibody and} Blockade of TLR4 on TLR4 Gene Expression during LPSInduced Inflammation. TLR4 gene expression was detected in four analysed hypothalamic structures and in the AP. Concomitant administration of LPS (iv) and anti-LPS (icv) increased $(P<0.05)$ mRNA TLR4 level in the MBH but decreased $(P<0.01)$ it in the AP compared with $\mathrm{NaCl}$ control group. It has been shown that the administration of LPS (iv) together with antibodies binding TLR4 receptor complex components anti-LBP and anti-MD2 (icv) increased TLR4

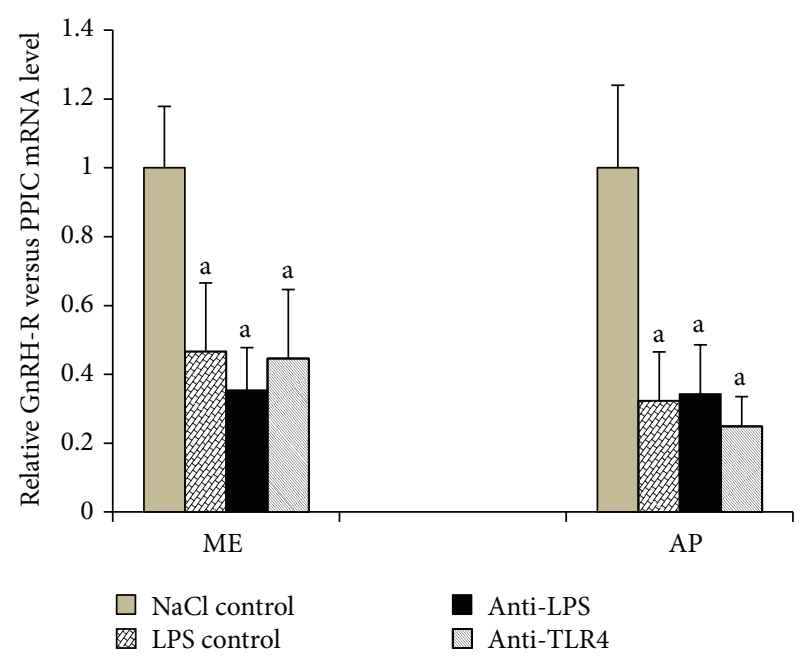

FIGURE 5: The effect of central injection of LPS antibody and blockade of TLR4 on the relative GnRH-R mRNA level in the $\mathrm{ME}$ and the AP during LPS-induced inflammation. Each point represents mean \pm SEM; “a” indicate values that differ significantly according to the Mann-Whitney $U$ test from "NaCl control" $(P<$ $0.01)$.

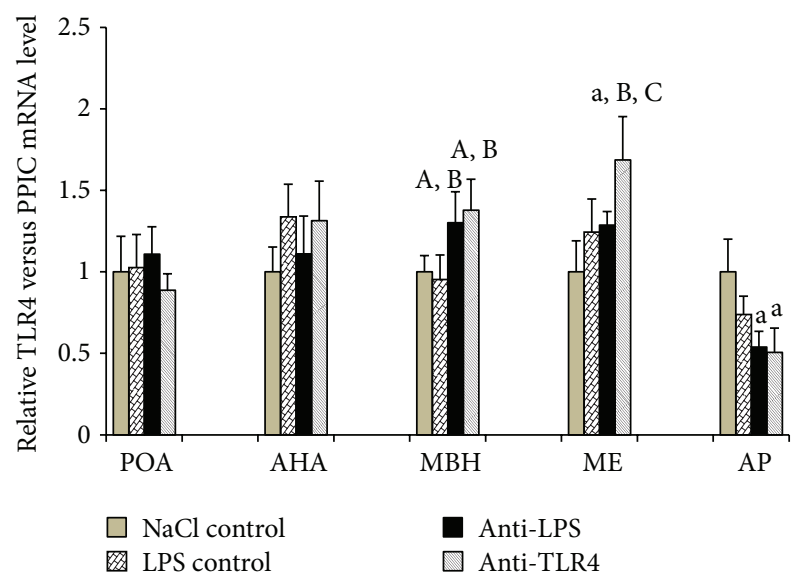

FIGURE 6: The effect of central injection of LPS antibody and blockade of TLR4 on the relative TLR4 mRNA level in the hypothalamic structures (POA, AHA, MBH, and ME) and in the AP during LPSinduced inflammation. Each point represents mean \pm SEM. Letters indicate values that differ significantly according to the MannWhitney $U$ test from "NaCl control" ( ${ }^{\mathrm{a}} P<0.01$; $\left.{ }^{\mathrm{A}} P<0.05\right)$; "LPS control" ( $\left.{ }^{\mathrm{B}} P<0.05\right)$; "anti-LPS" ( $\left.{ }^{\mathrm{C}} P<0.05\right)$, respectively.

gene expression in the ME compared with the other groups (NaCl control: $P<0.01$; LPS control: $P<0.05$; anti-LPS: $P<0.05)$. An increase $(P<0.05 ; P<0.05)$ of TLR4 gene expression in anti-TLR4 group was also demonstrated in the $\mathrm{MBH}$ compared with $\mathrm{NaCl}$ control and LPS control groups, respectively, whereas a decrease $(P<0.01)$ in the AP compared with $\mathrm{NaCl}$ control group. In the POA and the AHA observed differences between analysed groups were not significant (Figure 6). 


\section{Discussion}

Our study shows the inhibitory effect of LPS-induced immune stress on LH secretion in sheep which is consistent with previous in vivo studies conducted on anestrous ewes $[15,16]$. Other researchers also showed that LPS affects LH secretion and even disturbs the preovulatory LH surge in ewes $[29,30]$. In castrated rams, LPS significantly reduced plasma LH level and the number of LH pulses [2]. Likewise, Refojo et al. [12] demonstrated that endotoxin lowered LH concentrations by inhibiting several pulsatility parameters such as frequency, amplitude, and maximum values in male rats.

The most important regulator of $\mathrm{LH}$ secretion is $\mathrm{GnRH}$, which affects reproduction processes at level of the CNS by stimulation of the gonadotrophs in the AP to secrete LH. Functional regulation of LH secretion is mediated by the pulsatile secretion of GnRH into the hypophyseal portal vasculature [31]. It has been demonstrated that pulsatile pattern of LH secretion is a direct reflection of $\mathrm{GnRH}$ secretion from hypothalamus in ovariectomized ewes [32]. Changes in LH secretion observed after peripheral injection of LPS suggest that immune stress acts on the reproductive functions at the level of the hypothalamus through alterations of GnRH secretion. Fergani et al. [33] showed that peripheral endotoxin administration caused disorders in the $\mathrm{GnRH} / \mathrm{LH}$ surge. It could be caused by less $\mathrm{GnRH}$ release or that pituitary responsiveness to GnRH may have been comprised. Previous studies on the ovine model clearly showed that administration of bacterial endotoxin induced an immune/inflammatory stress and reduced pulsatile $\mathrm{GnRH}$ secretion $[2,13]$.

In presented study, bacterial endotoxin lowered $G n R H$ mRNA level in the POA, where more than half of all GnRH perikarya are located [34]. It was determined that $G n R H$ mRNA level in the POA was the highest among other analysed hypothalamic structures, which confirms earlier reports that neurons located in the POA synthesized most of GnRH transcripts in anestrous phase ewes [15]. This fact further supports the assumption that activity of GnRHergic neurons in the hypothalamus is modulated by immune stress. However, it has not been proven that immune challenge affects the $\mathrm{GnRH}$ synthesis at the transcriptional or posttranscriptional levels. Observed changes in GnRH mRNA content in the hypothalamic area may not result from decreased $G n R H$ gene transcription which is fairly stable [35] but from lowered accumulation or increased degradation cytoplasmic $G n R H$ mRNA. This data suggests that the suppressive effect of immune stress on GnRH release to the hypophyseal portal blood previously described in sheep [36] could result from reduced $G n R H$ gene expression in the POA. It is worth to mention that in the present study there were no significant changes in $G n R H$ gene expression in the $\mathrm{MBH}$ and the amount of GnRH mRNA in the AHA was below the limit of detection, which is consistent with previously obtained results [15] and suggests that in anestrous ewes GnRH neurons located in these hypothalamic structures do not play pivotal role in communication between neuroendocrine and immune systems. It was also found that LPS significantly decreased GnRH gene expression in the ME, where GnRH neurons terminals are located. This phenomenon has been described in detail in our previous study [15] and it has been suggested that the selective transport of $G n R H$ transcript to the distal part of neurons occurred in the GnRHergic neurons. Decreased content of GnRH in the ME after LPS treatment could result from decreased transport of GnRH mRNA to the nerves terminals as well as increased degradation of $G n R H$ transcript in this structure. It was previously found that a gradual reduction of the poly $(\mathrm{A})$ tail of mRNA occurs during its translocation from the perykaryon to the nerve terminal [37-39]. Therefore, it may be assumed that mRNA stored in nerves terminals is more sensitive to all factors affecting the stability of these transcripts than mRNA that occurs in the region of the neuronal body.

In the present study, decreased GnRH-R gene expression after LPS administration was determined in the AP and ME. It supports the previous studies carried out on ovariectomized ewes that immune stress lowered $G n R H-R$ gene expression in the pituitary gland [40]. Similar results were also obtained in rats where the administration of LPS affected the GnRH-R expression both in hypothalamus and pituitary [41]. The decrease in the level of GnRH-R mRNA in the AP may be due to lower gonadotrophs stimulation by $\mathrm{GnRH}$, which is the main factor controlling the amount of its receptors [42]. In turn, the reduction of $G n R H-R$ gene expression may lead to a decrease GnRH-R expression in gonadotrophs and lower sensitivity of these cells on GnRH stimulation. This may lead to lower LH- $\beta$ synthesis in the AP.

In the presented study, the injection of endotoxin significantly increased the plasma level of cortisol. It fully supports the previous studies reported about stimulatory effect of immune stress on cortisol release in various animal species including sheep $[2,16,20,43]$. The elevation of the cortisol release suggests the activation of the hypothalamicpituitary-adrenal (HPA) axis, which may result in inhibition of the HPG axis $[2,43]$. Immune challenge stimulates the synthesis of HPA axis components, such as arginine vasopressin, corticotropin-releasing hormone $(\mathrm{CRH})$, adrenocorticotrophic hormone, and corticosterone/cortisone from adrenal cortex $[44,45]$. All these factors have an inhibitory effect on the HPG axis $[46,47]$. However, the role of cortisol and other HPA axis components in the suppression of the GnRH/LH secretion during immune stress seems to be ambiguous. Rivest and Rivier [48] demonstrated in rats that reproductive system inhibited by LPS injection has not been released from its suppressive action by CRH antibodies administration, although this administration prevented the increase in the HPA axis activity. In study carried out on sheep, Debus et al. [43] demonstrated that the cortisol secretion blockage did not lower the suppression of $\mathrm{GnRH} / \mathrm{LH}$ release caused by LPS treatment.

One of the mechanisms through endotoxin that may modulate the neuroendocrine system is induction of proinflammatory cytokines $[23,49]$. However, the main source of centrally acting cytokines seems to be their local synthesis in the brain parenchyma [50]. These cytokines can be also secreted by the BBB cells activated by endotoxin $[23,51,52]$ as well as the choroid plexus cells [53]. It is worth mentioning 
that some amounts of the central cytokines could have a peripheral origin and cross the $\mathrm{BBB}$ due to the existence of saturated transport mechanism [54]. Another possible pathway of endotoxin penetration to the brain is through the organum vasculosum laminae terminalis (OVLT), which is one of the sensory circumventricular organs, forming the anterior wall of the third ventricle [55]. This structure is devoid of the BBB, so OVLT could be a potential location for LPS bypassing into the brain parenchyma. A direct response of OVLT cells to exposure to endotoxin or cytokines was demonstrated by Ott et al. [56]. Their study showed that the OVLT cells secrete proinflammatory cytokines (e.g., TNF- $\alpha$, IL-1 $\beta$, and IL-6). It has been previously reported that LPS acting indirectly via stimulation of central cytokines synthesis affects GnRH secretion in the hypothalamus and can disturb LH secretion from the AP $[13,18,19]$.

On the other hand, one of the mechanisms by which peripherally administered endotoxin affects central response is the activation of the afferent vagal nerves by prostaglandins (PGs), other important regulatory factors of $\mathrm{GnRH} / \mathrm{LH}$ levels suppression during immune stress [57]. Rettori et al. [58] showed that inhibition of prostaglandin $\mathrm{E}_{2}\left(\mathrm{PGE}_{2}\right)$ suppressed the release of $\mathrm{GnRH} / \mathrm{LH}$. This inhibition could be caused via PG-dependent pathways. Peripheral administration of LPS induces synthesis of endogenous cytokines (e.g., IL-1 $\beta$ ) and activates the projection area of the vagal nerves in the brain [59]. Presence of receptors for IL-1 was demonstrated in study of Ek et al. [60] which suggested that IL-1 $\beta$ stimulates vagal sensory activity. This activation of afferent nerve fibers by peripherally released cytokines could be a fast pathway of immune signals transfer from the periphery to the brain. However, in response to circulating cytokines, a slow humoral pathway of transmission is activated [61]. Immune challenge could act as well in this PG-dependent manner represented by PGs synthesis by cyclooxygenase-2 (COX-2) around blood vessels [62]. These observations suggest that PGs play a role in mediating between the immune and neuroendocrine systems $[57,63]$.

In our study, TLR4 gene expression was determined in the hypothalamic structures such as the POA, AHA, $\mathrm{MBH}$, and ME and in the AP. However, no effect of LPS administration on TLR4 transcription in all these structures was observed. These results are partially contrary to our previous study performed on anestrous ewes [20] where significant increase of the TLR4 gene expression was determined. The existence of TLR4 receptor in the hypothalamus may suggest the possible direct action of LPS in the CNS. Although experiments carried out on cats [64] seem to exclude the penetration of endotoxin from the blood to the brain, the results of experiments conducted on rats are inconclusive. Singh and Jiang [23] suggest that LPS modulates the permeability of the BBB but does not exceed it. However, in vivo research performed on mice [22] and rats [65] have shown that iodine-radiolabelled LPS penetrated the $\mathrm{BBB}$ in measured quantities. The study performed on rats showed that central administration of endotoxin suppressed the secretion of LH in rats [66]. This proves the potential of centrally acting LPS to suppress the HPG activity at the hypothalamic level. In present study, it was determined that the blockade of TLR4 receptor in the hypothalamus as well as administration of anti-LPS antibody into the region of hypothalamus reverses decreasing effect of LPS treatment on GnRH mRNA level in the ME. However, no effects of these treatments were observed in the structures where $\mathrm{GnRH}$ neurons perikarya are located. The fact that the blockade of TLR4 receptor as well as administration of anti-LPS antibody into the third ventricle restored $G n R H$ mRNA content only in the ME suggests that these treatments prevented the inflammation, dependent decreasing of the $G n R H$ mRNA stability rather than decreasing $G n R H$ gene transcription. The inhibition of TLR4 receptor as well as decreasing the number of its interacting ligand could result in decreased proinflammatory cytokines synthesis in the hypothalamus. It was previously suggested that acting in the region of hypothalamus proinflammatory IL- $1 \beta$ could be responsible for decreasing the stability of $G n R H$ mRNA and reduction of its translation [19].

In our study, restoration of $L H-\beta$ mRNA content to the control level was observed only in the anti-TLR4 group. However, this change in the $L H-\beta$ gene expression was not accompanied by the elevation of the circulating $\mathrm{LH}$ concentration. The lack of parallelism between the increased LH transcription and the peripheral level of LH in the antiTLR4 group suggests that LH release was still inhibited by the peripheral immune/inflammatory challenges affecting the HPG axis at the pituitary level. This suppression may result from the action of proinflammatory cytokines whose receptors are widespread in the pituitary gland [67]. The results of our ex vivo study showed that IL-1 $\beta$ is a potent downregulator of LH secretion directly from the pituitary and suggested that this direct action of interleukin could have a profound effect on the suppression of LH release occurring during an inflammatory state [68]. The in vitro study performed on the mouse AtT-20 pituitary tumor cells showed that direct LPS treatment increases the number of IL-1R1 in a dosedependent manner [69]. The studies carried out on mice [70] and sheep [71] also reported the stimulating effect of LPS on IL-1R1 mRNA. Another inflammatory cytokine involved in direct modulation of the secretory activity of the pituitary is IL-6. The in vitro study showed that IL-6 significantly suppressed $\mathrm{GnRH}$-stimulated $\mathrm{LH}$ release from male rats dispersed pituitaries throughout the dose range but did not influence basal LH release [72]. It is worth mentioning that stress caused by LPS injection may increase the number of cytokines receptors expressed in the AP [73]. The factor suppressing the $\mathrm{LH}$ secretion at the level of pituitary could be also LPS itself. Our previous ex vivo study showed that LPS directly decreases LH secretion from the ovine AP explants [74]. It was suggested that the secretion of LH from the pituitary could be affected directly by LPS and/or could result from autocrine action of proinflammatory cytokines secrete by the folliculostellate cells.

\section{Conclusions}

The study suggests that the blockade of TLR4 receptor in the hypothalamus during LPS-induced immune stress restores 
the $L H-\beta$ transcription in the pituitary gland. However, this treatment is not sufficient to unblock the release of LH suppressed by the peripheral immune/inflammatory challenges.

\section{Conflict of Interests}

All authors declare that there is no conflict of interests regarding the publication of this paper.

\section{Acknowledgment}

This research was supported by Grant NCN 5164/B/P01/ 2011/40.

\section{References}

[1] A. T. Peter, W. T. Bosu, and R. J. DeDecker, "Suppression of preovulatory luteinizing hormone surges in heifers after intrauterine infusions of Escherichia coli endotoxin," The American Journal of Veterinary Research, vol. 50, no. 3, pp. 368-373, 1989.

[2] E. S. Coleman, T. H. Elsasser, R. J. Kemppainen, D. A. Coleman, and J. L. Sartin, "Effect of endotoxin on pituitary hormone secretion in sheep," Neuroendocrinology, vol. 58, no. 1, pp. 111122, 1993.

[3] S. Rivest, S. Lee, B. Attardi, and C. Rivier, "The chronic intracerebroventricular infusion of interleukin- $1 \beta$ alters the activity of the hypothalamic-pituitary-gonadal axis of cycling rats. I. Effect on LHRH and gonadotropin biosynthesis and secretion," Endocrinology, vol. 133, no. 6, pp. 2424-2430, 1993.

[4] E. Xiao, L. Xia-Zhang, and M. Ferin, "Inhibitory effects of endotoxin on LH secretion in the ovariectomized monkey are prevented by naloxone but not by an interleukin-1 receptor antagonist," NeuroImmunoModulation, vol. 7, no. 1, pp. 6-15, 1999.

[5] E. T. Reitschel, T. Kirikae, F. U. Shade et al., "Bacterial endotoxin: molecular relationships of structure to activity and function," The FASEB Journal, vol. 8, no. 2, pp. 217-225, 1994.

[6] T. L. Gioannini and J. P. Weiss, "Regulation of interactions of Gram-negative bacterial endotoxins with mammalian cells," Immunologic Research, vol. 39, no. 1-3, pp. 249-260, 2007.

[7] K. Miyake, "Innate immune sensing of pathogens and danger signals by cell surface Toll-like receptors," Seminars in Immunology, vol. 19, no. 1, pp. 3-10, 2007.

[8] K. A. Fitzgerald, D. C. Rowe, and D. T. Golenbock, "Endotoxin recognition and signal transduction by the TLR4/MD2complex," Microbes and Infection, vol. 6, no. 15, pp. 1361-1367, 2004.

[9] H. Mitsuzawa, C. Nishitani, N. Hyakushima et al., "Recombinant soluble forms of extracellular TLR4 domain and MD-2 inhibit lipopolysaccharide binding on cell surface and dampen lipopolysaccharide-induced pulmonary inflammation in mice," Journal of Immunology, vol. 177, no. 11, pp. 8133-8139, 2006.

[10] G. Zhang and S. Ghosh, "Negative regulation of toll-like receptor-mediated signaling by Tollip," Journal of Biological Chemistry, vol. 277, no. 9, pp. 7059-7065, 2002.

[11] C. G. Leon, R. Tory, J. Jia, O. Sivak, and K. M. Wasan, “Discovery and development of toll-like receptor 4 (TLR4) antagonists: a new paradigm for treating sepsis and other diseases," Pharmaceutical Research, vol. 25, no. 8, pp. 1751-1761, 2008.

[12] D. Refojo, P. Arias, J. A. Moguilevsky, and C. Feleder, "Effect of bacterial endotoxin on in vivo pulsatile gonadotropin secretion in adult male rats," Neuroendocrinology, vol. 67, no. 4, pp. 275281, 1998.

[13] J. A. Daniel, M. S. Abrams, L. DeSouza, C. G. Wagner, B. K. Whitlock, and J. L. Sartin, "Endotoxin inhibition of luteinizing hormone in sheep," Domestic Animal Endocrinology, vol. 25, no. 1, pp. 13-19, 2003.

[14] C. Suzuki, K. Yoshioka, S. Iwamura, and H. Hirose, "Endotoxin induces delayed ovulation following endocrine aberration during the proestrous phase in Holstein heifers," Domestic Animal Endocrinology, vol. 20, no. 4, pp. 267-278, 2001.

[15] A. P. Herman and D. Tomaszewska-Zaremba, "Effect of endotoxin on the expression of GnRH and GnRHR genes in the hypothalamus and anterior pituitary gland of anestrous ewes," Animal Reproduction Science, vol. 120, no. 1-4, pp. 105-111, 2010.

[16] A. P. Herman, K. Romanowicz, and D. Tomaszewska-Zaremba, "Effect of LPS on reproductive system at the level of the pituitary of anestrous ewes," Reproduction in Domestic Animals, vol. 45, no. 6, pp. e351-e359, 2010.

[17] L. Givalois, J. Dornand, M. Mekaouche et al., "Temporal cascade of plasma level surges in ACTH, corticosterone, and cytokines in endotoxin-challenged rats," The American Journal of Physiology-Regulatory Integrative and Comparative Physiology, vol. 267, no. 1, pp. R164-R170, 1994.

[18] H. Watanobe and Y. Hayakawa, "Hypothalamic interleukin- $1 \beta$ and tumor necrosis factor- $\alpha$, but not interleukin- 6 , mediate the endotoxin-induced suppression of the reproductive axis in rats," Endocrinology, vol. 144, no. 11, pp. 4868-4875, 2003.

[19] A. P. Herman, T. Misztal, K. Romanowicz, and D. TomaszewskaZaremba, "Central injection of exogenous IL-1 $\beta$ in the control activities of hypothalamic-pituitary-gonadal axis in anestrous ewes," Reproduction in Domestic Animals, vol. 47, no. 1, pp. 4452, 2012.

[20] A. P. Herman, A. Herman, K. Haziak, and D. TomaszewskaZaremba, "Immune stress up regulates TLR4 and Tollip gene expression in the hypothalamus of ewes," Journal of Animal and Feed Sciences, vol. 22, no. 1, pp. 13-18, 2013.

[21] S. Chakravarty and M. Herkenham, "Toll-like receptor 4 on nonhematopoietic cells sustains CNS inflammation during endotoxemia, independent of systemic cytokines," Journal of Neuroscience, vol. 25, no. 7, pp. 1788-1796, 2005.

[22] W. A. Banks and S. M. Robinson, "Minimal penetration of lipopolysaccharide across the murine blood-brain barrier," Brain, Behavior, and Immunity, vol. 24, no. 1, pp. 102-109, 2010.

[23] A. K. Singh and Y. Jiang, "How does peripheral lipopolysaccharide induce gene expression in the brain of rats?" Toxicology, vol. 201, no. 1-3, pp. 197-207, 2004.

[24] W. Traczyk and F. Przekop, "Methods of investigation of the function of the hypothalamus and hypophysis in chronic experiments in sheep," Acta physiologica Polonica, vol. 14, pp. 217-226, 1963.

[25] R. Stupnicki and A. Madej, "Radioimmunoassay of LH in blood plasma of farm animals," Endokrinologie, vol. 68, no. 1, pp. 6-13, 1976.

[26] F. Kokot and R. Stupnicki, Eds., Radioimmunological and Radiocompetitive Methods Used in Clinical Studies, PZWL, Warsaw, Poland, 2nd edition, 1985 (Polish).

[27] R. Rasmussen, "Quantification on the LightCycler," in Rapid Cycle Real-Time PCR-Methods and Applications, S. Meuer, C. Wittwer, and K. Nakagawara, Eds., pp. 21-34, Springer, Berlin, Germany, 2001. 
[28] M. W. Pfaffl, A. Tichopad, C. Prgomet, and T. P. Neuvians, "Determination of stable housekeeping genes, differentially regulated target genes and sample integrity: bestkeeper-excelbased tool using pair-wise correlations," Biotechnology Letters, vol. 26, no. 6, pp. 509-515, 2004.

[29] D. F. Battaglia, A. B. Beaver, T. G. Harris, E. Tanhehco, C. Viguié, and F. J. Karsch, "Endotoxin disrupts the estradiol-induced luteinizing hormone surge: interference with estradiol signal reading, not surge release," Endocrinology, vol. 140, no. 6, pp. 2471-2479, 1999.

[30] F. J. Karsch and D. F. Battaglia, "Mechanisms for endotoxininduced disruption of ovarian cyclicity: observations in sheep," Reproduction Supplement, vol. 59, pp. 101-113, 2002.

[31] G. L. Williams, J. F. Thorson, L. D. Prezotto, I. C. Velez, R. C. Cardoso, and M. Amstalden, "Reproductive seasonality in the mare: neuroendocrine basis and pharmacologic control," Domestic Animal Endocrinology, vol. 43, no. 2, pp. 103-115, 2012.

[32] I. J. Clarke and S. Pompolo, "Synthesis and secretion of GnRH," Animal Reproduction Science, vol. 88, no. 1-2, pp. 29-55, 2005.

[33] C. Fergani, A. K. Saifullizam, J. E. Routly, R. F. Smith, and H. Dobson, "Estrous behavior, luteinizing hormone and estradiol profiles of intact ewes treated with insulin or endotoxin," Physiology and Behavior, vol. 105, no. 3, pp. 757-765, 2012.

[34] M. Caldani, M. Batailler, J. C. Thiery, and M. P. Dubois, "LHRHimmunoreactive structures in the sheep brain," Histochemistry, vol. 89, no. 2, pp. 129-139, 1988.

[35] A. C. Gore, GnRH: The Master Molecule of Reproduction, Springer, Berlin, Germany, 1st edition, 2002.

[36] D. F. Battaglia, J. M. Bowen, H. B. Krasa, L. A. Thrun, C. Viguié, and F. J. Karsch, "Endotoxin inhibits the reproductive neuroendocrine axis while stimulating adrenal steroids: a simultaneous view from hypophyseal portal and peripheral blood," Endocrinology, vol. 138, no. 10, pp. 4273-4281, 1997.

[37] E. Mohr, S. Fehr, and D. Richter, "Axonal transport of neuropeptide encoding mRNAs within the hypothalamo-hypophyseal tract of rats," EMBO Journal, vol. 10, no. 9, pp. 2419-2424, 1991.

[38] D. Maciejewski-Lenoir, G. F. Jirikowski, P. P. Sanna, and F. E. Bloom, "Reduction of exogenous vasopressin RNA poly(A) tail length increases its effectiveness in transiently correcting diabetes insipidus in the Brattleboro rat," Proceedings of the National Academy of Sciences of the United States of America, vol. 90, no. 4, pp. 1435-1439, 1993.

[39] C. Jiang and E. M. Schuman, "Regulation and function of local protein synthesis in neuronal dendrites," Trends in Biochemical Sciences, vol. 27, no. 10, pp. 506-513, 2002.

[40] C. Y. Williams, T. G. Harris, D. F. Battaglia, C. Viguié, and F. J. Karsch, "Endotoxin inhibits pituitary responsiveness to gonadotropin-releasing hormone," Endocrinology, vol. 142, no. 5, pp. 1915-1922, 2001.

[41] R. E. Nappi and S. Rivest, "Effect of immune and metabolic challenges on the luteinizing hormone-releasing hormone neuronal system in cycling female rats: an evaluation at the transcriptional level," Endocrinology, vol. 138, no. 4, pp. 1374-1384, 1997.

[42] L. A. Rispoli and T. M. Nett, "Pituitary gonadotropin-releasing hormone (GnRH) receptor: structure, distribution and regulation of expression," Animal Reproduction Science, vol. 88, no. 1-2, pp. 57-74, 2005.

[43] N. Debus, K. M. Breen, G. K. Barrell et al., "Does cortisol mediate endotoxin-induced inhibition of pulsatile luteinizing hormone and gonadotropin-releasing hormone secretion?" Endocrinology, vol. 143, no. 10, pp. 3748-3758, 2002.
[44] F. Dadoun, V. Guillaume, N. Sauze et al., "Effect of endotoxin on the hypothalamic-pituitary-adrenal axis in sheep," European Journal of Endocrinology, vol. 138, no. 2, pp. 193-197, 1998.

[45] S. Melmed, “The immuno-neuroendocrine interface," Journal of Clinical Investigation, vol. 108, no. 11, pp. 1563-1566, 2001.

[46] H. Dobson, S. Ghuman, S. Prabhakar, and R. Smith, "A conceptual model of the influence of stress on female reproduction," Reproduction, vol. 125, no. 2, pp. 151-163, 2003.

[47] K. Maeda and H. Tsukamura, "The impact of stress on reproduction: are glucocorticoids inhibitory or protective to gonadotropin secretion?" Endocrinology, vol. 147, no. 3, pp. 1085-1086, 2006.

[48] S. Rivest and C. Rivier, "The role of corticotropin-releasing factor and interleukin-1 in the regulation of neurons controlling reproductive functions," Endocrine Reviews, vol. 16, no. 2, pp. 177-199, 1995.

[49] J. J. Haddad, N. E. Saadé, and B. Safieh-Garabedian, "Cytokines and neuro-immune-endocrine interactions: a role for the hypothalamic-pituitary-adrenal revolving axis," Journal of Neuroimmunology, vol. 133, no. 1-2, pp. 1-19, 2002.

[50] L. Vitkovic, J. Bockaert, and C. Jacque, "Inflammatory' cytokines' neuromodulators in normal brain?" Journal of Neurochemistry, vol. 74, no. 2, pp. 457-471, 2000.

[51] T. Kaisho and S. Akira, "Toll-like receptor function and signaling," Journal of Allergy and Clinical Immunology, vol. 117, no. 5, pp. 979-987, 2006.

[52] S. Y. S. Feng, V. Y. H. Yu, and A. M. Walker, "Endotoxin-induced circulatory changes in the newborn brain: a review," Hong Kong Journal of Paediatrics, vol. 12, no. 2, pp. 111-117, 2007.

[53] K. Mitchell, H. Y. Yang, J. D. Berk, J. H. Tran, and M. J. Iadarola, "Monocyte chemoattractant protein-1 in the choroid plexus: a potential link between vascular pro-inflammatory mediators and the CNS during peripheral tissue inflammation," Neuroscience, vol. 158, no. 2, pp. 885-895, 2009.

[54] N. G. Carlson, W. A. Wieggel, J. Chen, A. Bacchi, S. W. Rogers, and L. C. Gahring, "Inflammatory cytokines IL- $1 \alpha$, IL-1 $\beta$, IL-6, and TNF- $\alpha$ impart neuroprotection to an excitotoxin through distinct pathways," Journal of Immunology, vol. 163, no. 7, pp. 3963-3968, 1999.

[55] A. K. Johnson and P. M. Gross, "Sensory circumventricular organs and brain homeostatic pathways," The FASEB Journal, vol. 7, no. 8, pp. 678-686, 1993.

[56] D. Ott, J. Murgott, S. Rafalzik et al., "Neurons and glial cells of the rat organum vasculosum laminae terminalis directly respond to lipopolysaccharide and pyrogenic cytokines," Brain Research, vol. 1363, no. 6, pp. 93-106, 2010.

[57] T. G. Harris, D. F. Battaglia, M. E. Brown et al., "Prostaglandins mediate the endotoxin-induced suppression of pulsatile gonadotropin-releasing hormone and luteinizing hormone secretion in the ewe," Endocrinology, vol. 141, no. 3, pp. 1050-1058, 2000.

[58] V. Rettori, M. F. Gimeno, A. Karara, M. C. Gonzalez, and S. M. McCann, "Interleukin $1 \alpha$ inhibits prostaglandin E2 release to suppress pulsatile release of luteinizing hormone but not follicle-stimulating hormone," Proceedings of the National Academy of Sciences of the United States of America, vol. 88, no. 7, pp. 2763-2767, 1991.

[59] R. Dantzer, "Cytokine-induced sickness behavior: where do we stand?" Brain, Behavior, and Immunity, vol. 15, no. 1, pp. 7-24, 2001. 
[60] M. Ek, M. Kurosawa, T. Lundeberg, and A. Ericsson, "Activation of vagal afferents after intravenous injection of interleukin- $1 \beta$ : role of endogenous prostaglandins," Journal of Neuroscience, vol. 18, no. 22, pp. 9471-9479, 1998.

[61] J. P. Konsman, P. Parnet, and R. Dantzer, "Cytokine-induced sickness behaviour: mechanisms and implications," Trends in Neurosciences, vol. 25, no. 3, pp. 154-159, 2002.

[62] C. Cao, K. Matsumura, K. Yamagata, and Y. Watanabe, "Involvement of cyclooxygenase-2 in LPS-induced fever and regulation of its mRNA by LPS in the rat brain," The American Journal of Physiology-Regulatory Integrative and Comparative Physiology, vol. 272, no. 6, pp. R1712-R1725, 1997.

[63] D. Tomaszewska-Zaremba, A. P. Herman, and T. Misztal, "Does central IL-1? affect GnRH secretion in the hypothalamus of anestrous ewes via different regulatory pathways?" Journal of Animal and Feed Sciences, vol. 22, no. 1, pp. 5-12, 2013.

[64] M. J. Dascombe and A. S. Milton, "Study on the possible entry of bacterial endotoxin and prostaglandin E2 into the central nervous system from the blood," British Journal of Pharmacology, vol. 66, no. 4, pp. 565-572, 1979.

[65] G. Chen, R. S. McCuskey, and S. Reichlin, "Blood interleukin6 and tumor necrosis factor- $\alpha$ elevation after intracerebroventricular injection of Escherichia coli endotoxin in the rat is determined by two opposing factors: peripheral induction by LPS transferred from brain to blood and inhibition of peripheral response by a brain-mediated mechanism," NeuroImmunoModulation, vol. 8, no. 2, pp. 59-69, 2000.

[66] O. Ebisui, J. Fukata, T. Tominaga et al., "Roles of interleukin$1 \alpha$ and $-1 \beta$ in endotoxin-induced suppression of plasma gonadotropin levels in rats," Endocrinology, vol. 130, no. 6, pp. 3307-3313, 1992.

[67] A. Kariagina, D. Romanenko, S. G. Ren, and V. Chesnokova, "Hypothalamic-pituitary cytokine network," Endocrinology, vol. 145, no. 1, pp. 104-112, 2004.

[68] A. P. Herman, A. Krawczyńska, J. Bochenek, E. Dobek, A. Herman, and D. Tomaszewska-Zaremba, "LPS-induced inflammation potentiates the IL- $1 \beta$-mediated reduction of LH secretion from the anterior pituitary explants," Clinical and Developmental Immunology, vol. 2013, Article ID 926937, 7 pages, 2013.

[69] C. Kumagai, T. Takao, R. Matsumoto, K. Asaba, and K. Hashimoto, "Modulation of interleukin-1 receptors followed by endotoxin lipopolysaccharide treatment in the mouse AtT-20 pituitary tumor cell line," NeuroImmunoModulation, vol. 10, no. 5, pp. 310-316, 2002.

[70] M. M. Gabellec, R. Griffais, G. Fillion, and F. Haour, "Interleukin-1 receptors type I and type II in the mouse brain: kinetics of mRNA expressions after peripheral administration of bacterial lipopolysaccharide," Journal of Neuroimmunology, vol. 66, no. 1-2, pp. 65-70, 1996.

[71] A. P. Herman, T. Misztal, A. Herman, and D. TomaszewskaZaremba, "Expression of Interleukin (IL)-1 $\beta$ and IL-1 receptors genes in the hypothalamus of anoestrous ewes after lipopolysaccharide treatment," Reproduction in Domestic Animals, vol. 45, no. 6, pp. e426-e433, 2010.

[72] S. H. Russell, C. J. Small, S. A. Stanley, S. Franks, M. A. Ghatei, and S. R. Bloom, "The in vitro role of tumour necrosis factoralpha and interleukin- 6 in the hypothalamic-pituitary gonadal axis," Journal of Neuroendocrinology, vol. 13, no. 3, pp. 296-301, 2001.

[73] T. Takao, K. Hashimoto, and E. B. de Souza, "Modulation of interleukin-1 receptors in the brain-endocrine-immune axis by stress and infection," Brain, Behavior, and Immunity, vol. 9, no. 4, pp. 276-291, 1995.

[74] K. Haziak, A. P. Herman, and D. Tomaszewska-Zaremba, “The effect of LPS on LH release and gene expression of LH- $\beta$, GnRH-R and TLR4 in the anterior pituitary of follicular phase ewes-an in vitro study," Journal of Animal and Feed Sciences, vol. 22, no. 2, pp. 97-105, 2013. 


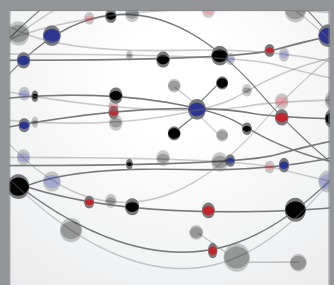

The Scientific World Journal
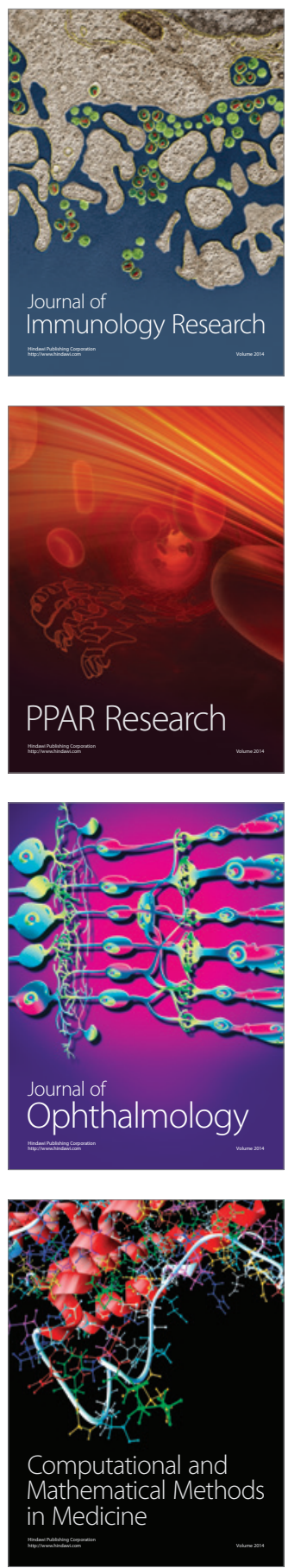

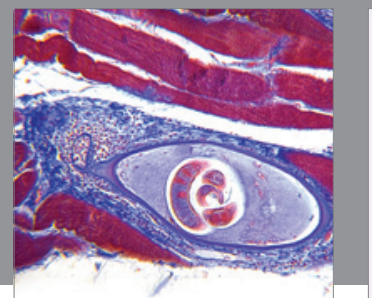

Gastroenterology

Research and Practice
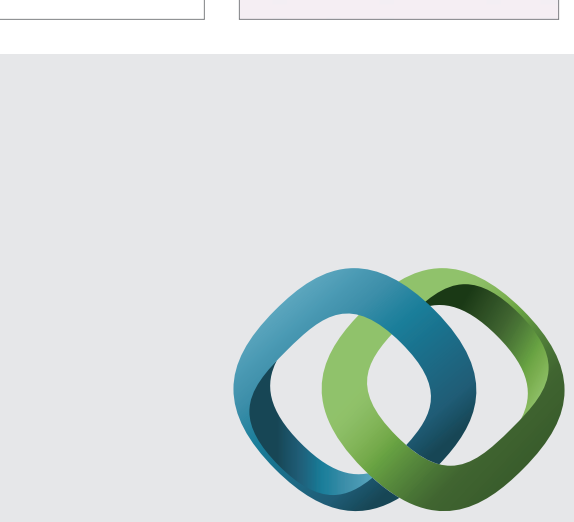

\section{Hindawi}

Submit your manuscripts at

http://www.hindawi.com
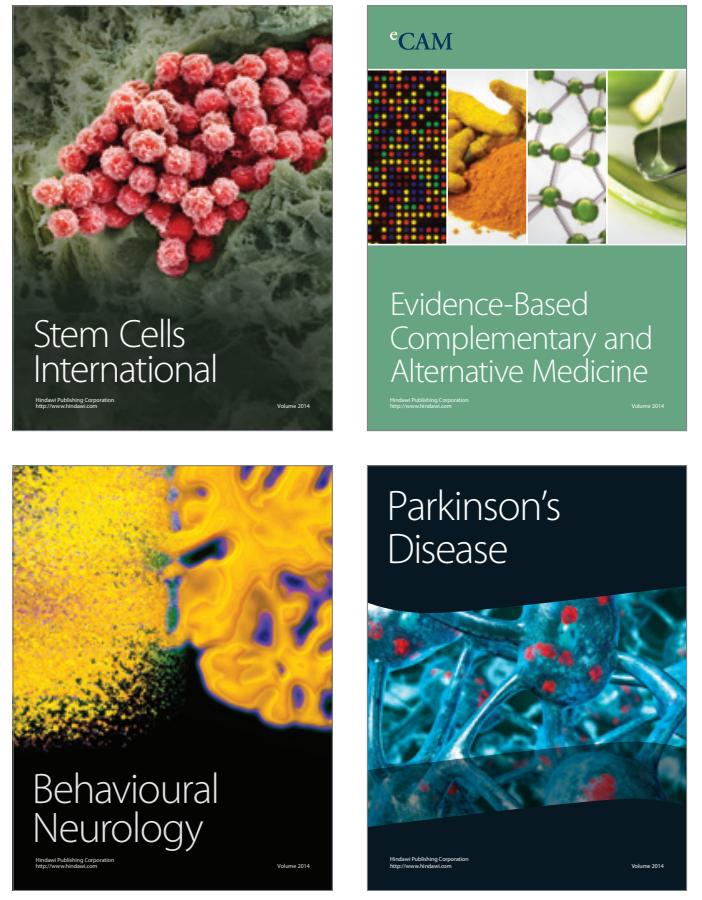
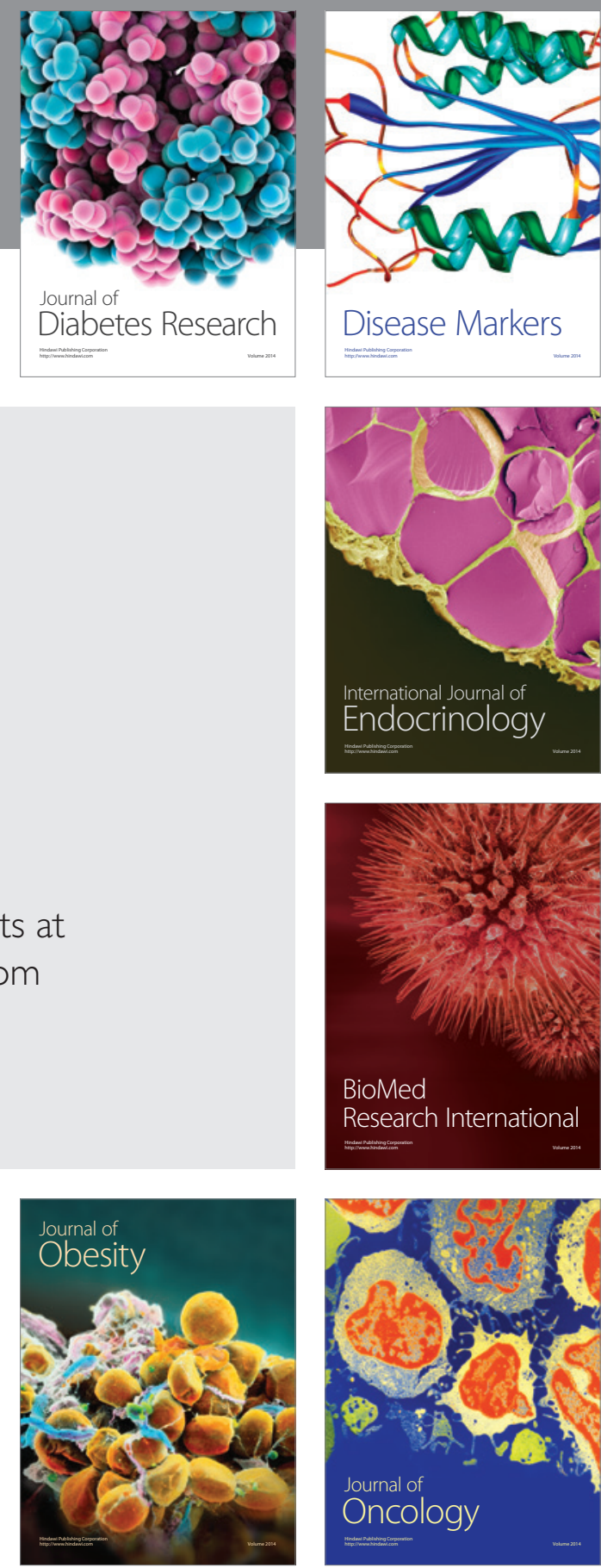

Disease Markers
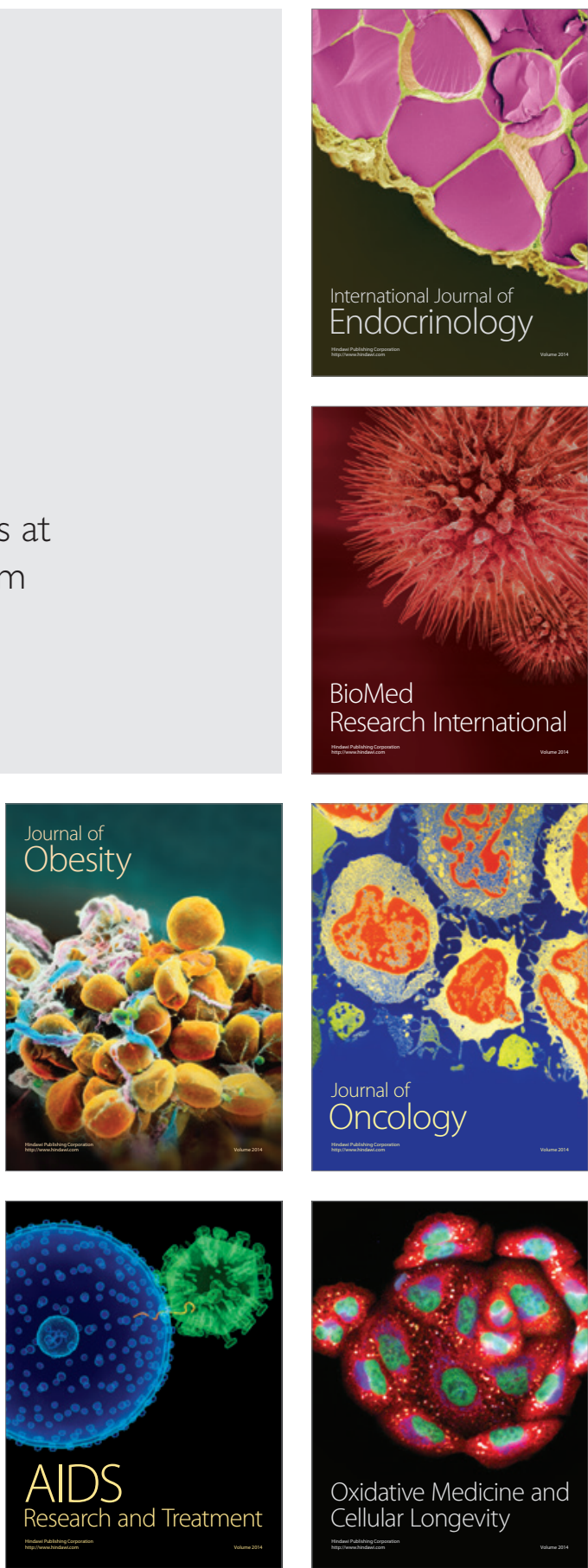